\title{
RECOMMENDATIONS FOR IMPROVING \\ THE AVAILABILITY AND THE QUALITY \\ OF TREATMENT SERVICE FOR GAMBLING \\ DISORDER PERSONS
}

\section{REKOMENDACJE DLA POPRAWY DOSTĘPNOŚCI I JAKOŚCI OFERTY LECZENIA ŚWIADCZONEJ OSOBOM Z ZABURZENIAMI HAZARDOWYMI}

\author{
Łukasz Wieczorek, Katarzyna Dąbrowska, Jacek Moskalewicz \\ Institute of Psychiatry and Neurology, Department of Studies on Alcoholism and Drug Dependence, Warsaw, Poland \\ Instytut Psychiatrii i Neurologii, Zakład Badań nad Alkoholizmem i Toksykomaniami, Warszawa, Polska
}

Alcohol Drug Addict 2017; 30 (2): 113-136

DOI: https://doi.org/10.5114/ain.2017.70289

\begin{abstract}
Introduction: The reasons for not taking treatment may include various social, cultural, individual and structural health system factors. The aim of the article is to present recommendations for improving the aid provision situation as regards people with gambling disorders and tailoring the service to their needs.

Material and methods: The qualitative method in the form of a semi-structured interview was used in the study. A total of 90 interviews were conducted; people with gambling disorders, employees of social welfare centres, therapists employed in addiction treatment centres (both for drug and alcohol dependence), general practitioners and psychiatrists were involved.
\end{abstract}

\begin{abstract}
Streszczenie
Wprowadzenie: Przyczyny niepodejmowania leczenia mogą obejmować różne czynniki społeczne, kulturowe, indywidualne i związane ze strukturą systemu pomocy. Celem artykułu jest przedstawienie rekomendacji dla poprawy sytuacji w zakresie świadczenia pomocy osobom $\mathrm{z}$ zaburzeniami hazardowymi i dostosowania oferty do ich potrzeb.

Materiał i metody: W badaniach wykorzystano metody badań jakościowych - technikę wywiadu semistrukturyzowanego. Łącznie przeprowadzono 90 wywiadów; wzięły w nich udział osoby z zaburzeniami hazardowymi, pracownicy ośrodków pomocy społecznej, terapeuci zatrudnieni w placówkach leczenia uzależnień (zarówno dla osób uzależnionych od
\end{abstract}

Correspondence to/Adres do korespondencji: Łukasz Wieczorek, Instytut Psychiatrii i Neurologii, Zakład Badań nad Alkoholizmem i Toksykomaniami, ul. Sobieskiego 9, 02-957 Warszawa, phone: +48 2245827 79, fax: +48 22 593 70 18, e-mail: lwieczorek@ipin.edu.pl

Authors' contribution/Wkład pracy autorów: Study design/Koncepcja pracy: Ł. Wieczorek, K. Dąbrowska, J. Moskalewicz / Data collection/Zebranie danych: Ł. Wieczorek, K. Dąbrowska / Statistical analysis/Analiza statystyczna: Ł. Wieczorek, K. Dąbrowska / Data interpretation/Interpretacja danych: $Ł$. Wieczorek, K. Dąbrowska, J. Moskalewicz / Acceptance of final manuscript version/ Akceptacja ostatecznej wersji: $Ł$. Wieczorek, K. Dąbrowska, J. Moskalewicz / Literature search/Przygotowanie literatury: $Ł$. Wieczorek, K. Dąbrowska / Funds collection/Pozyskanie środków (finansowania): Ł. Wieczorek, J. Moskalewicz

No ghostwriting and guest authorship declared./Nie występują zjawiska ghostwriting i guest authorship.

Submitted/Otrzymano: 18.05.2017 • Accepted/Przyjęto do druku: 07.07.2017 
Results: The recommendations identified in the study can be categorised into five areas: limiting the availability of gambling, information and education, increasing access to treatment, improving the quality and adequacy of treatment, and research. Within these areas more specific issues were divided.

Discussion: Introducing solutions with proven efficacy which limit the availability of alcoholic beverages to the field of gambling policy can be an effective way of limiting the prevalence of gambling and gambling related problems. Improving information and education strategies can increase the awareness in public opinion of the threat of gambling problems and bring attention to its importance among other social problems. In turn, increasing the availability of treatment and its quality and adequacy are important from the point of view of the barriers identified in the research that people undertaking therapy encounter.

Keywords: Gambling disorders, Treatment, Social welfare, Recommendations narkotyków, jak i od alkoholu), lekarze zatrudnieni w placówkach podstawowej opieki zdrowotnej i lekarze psychiatrzy.

Wyniki: Zidentyfikowane $\mathrm{w}$ badaniu rekomendacje można zakwalifikować do pięciu obszarów: ograniczanie dostępności hazardu, informacja i edukacja, zwiększanie dostępu do leczenia, poprawa jakości i adekwatności leczenia, badania naukowe. W ramach tych obszarów można wyróżnić kwestie bardziej szczegółowe.

Omówienie: Przeniesienie rozwiązań o dowiedzionej skuteczności, ograniczających dostępność napojów alkoholowych, na pole polityki hazardowej może skutecznie ograniczyć rozpowszechnienie grania i problemów z tym związanych. Poprawa strategii informacyjnej i edukacyjnej może zwiększyć świadomość zagrożenia problemem zaburzeń hazardowych $\mathrm{w}$ opinii publicznej oraz podnieść jego rangę wśród innych problemów. Z kolei zwiększenie dostępności leczenia oraz jego jakości i adekwatności są istotne z punktu widzenia zidentyfikowanych w badaniach barier, które napotykają osoby podejmujące terapię.

Słowa kluczowe: zaburzenia hazardowe, leczenie, pomoc społeczna, rekomendacje

\section{- INTRODUCTION}

Gambling problems appeared in Poland on a larger scale only after 1990 when the first casinos opened and the one-armed bandit slot machines appeared, lowering the barrier to the availability of gambling due to their dense network and lack of opening time limitations [1]. The problems were additionally exacerbated by the quick development of the Internet with its wide range of gambling games [2].

There are a number of distinctive terms in the subject literature like problem, compulsive and pathological gambling. Problem and pathological gambling are distinguished by the degree of disorder advancement. Persons with identified pathological gambling are at an later stage of dependency. In the Diagnostic and Statistical Manual of Mental Disorders, Fifth Edition (DSM-5), a new term, gambling disorders, was developed. This is increasingly employed to describe problems associated with gambling $[3,4]$.

\section{- Wprowadzenie}

Problemy $\mathrm{z}$ hazardem pojawiły się na większą skalę w Polsce dopiero po roku 1990, kiedy to otworzono pierwsze kasyna i na rynek weszły automaty do gier, dzięki którym - ze względu na ich gęstą sieć oraz brak ograniczeń co do godzin funkcjonowania - obniżył się próg dostępności hazardu [1]. Problemy zostały dodatkowo wzmocnione przez szybki rozwój Internetu, gdzie dostępna jest szeroka oferta gier hazardowych [2].

W literaturze przedmiotu wyróżnia się kilka różnych terminów: hazard problemowy, kompulsywny/przymusowy i patologiczny. Hazard problemowy od patologicznego odróżnia stopień zaawansowania zaburzenia. Osoby z rozpoznaniem hazardu patologicznego są na późniejszym etapie uzależnienia. W klasyfikacji DSM-5 wyróżniono nowy termin - zaburzenia hazardowe (gambling disorders), który jest coraz częściej wykorzystywany do opisu problemów związanych z hazardem $[3,4]$. 
The prevalence of gambling disorders in the global general population differs with region. The results of North American studies show the lifetime prevalence of pathological gambling in the adult population at $1.9 \%$ and problem gambling at $4.2 \%$ [5]. In Brazil, the prevalence of pathological and problem gambling in the year prior to the study was $1 \%$ and $1.3 \%$ respectively [6]. In other international studies, the prevalence of gambling disorders in the year prior to the study varied from $0.3 \%$ in Sweden, $0.6 \%$ in Germany, $0.7 \%$ in the United Kingdom to $5.3 \%$ in Hong Kong [7-9] and in North America it varied from $0.3 \%$ to $3.5 \%$ [10]. Meanwhile, in Australia, 2.3\% of adults had a gambling problems [11]. In Poland, the symptoms of gambling disorders occurred in over $5 \%$ of respondents who were 15 years of age or above - nearly $4 \%$ revealed a low level of disorder, $0.7 \%$ average and in $0.7 \%$ of respondents problem gambling syndrome was detected [12].

Many studies show that only a few of those with diagnosed gambling disorders decide to take up treatment or participate in Gamblers Anonymous meetings $[13,14]$. In the United States, between $7.1 \%$ and $9.9 \%$ of persons with gambling disorders sought help in treatment $[15,16]$. In Ontario, Canada, $10 \%$ of problem gamblers and $29 \%$ of pathological gamblers undertook treatment or took part in Gamblers Anonymous meetings [17]. Similar results were obtained in studies conducted in Pacific region countries. In Australia, 23\% of persons experiencing gambling-related problems sought help, as did $7 \%$ with less intense problems [18]. In New Zealand, 10-15\% of persons with gambling disorders sought professional help [19].

The low-level of social knowledge of gambling disorders and the perception of gambling in moral rather than medical terms influences the social acceptance of behaviours of this kind and may determine the manner in which these problems are dealt with by independent coping rather than the seeking of specialist help $[2,4$, 20-22]. Apart from that, various social, cultural and individual factors associated with the structure of the aid system may contribute to the failure to seek treatment $[11,23,24]$. Similarly, as in the case of most other dependencies, treatment is the most costly answer to the problems created by substance use and other behavioural dependencies. Hence the need to undertake activity
Rozpowszechnienie zaburzeń hazardowych w populacji ogólnej na świecie jest zróżnicowane w zależności od rejonu. Wyniki badań północnoamerykańskich wskazują, że rozpowszechnienie hazardu patologicznego $\mathrm{w}$ dorosłej populacji na przestrzeni całego życia jest na poziomie $1,9 \%$, a problemowego na poziomie 4,2\% [5]. W Brazylii rozpowszechnienie hazardu patologicznego i problemowego $\mathrm{w}$ roku poprzedzającym badanie wynosiło odpowiednio: $1 \%$ i $1,3 \%$ [6]. W innych badaniach międzynarodowych występowanie zaburzeń hazardowym rok przed badaniem wahało się od $0,3 \% \mathrm{w}$ Szwecji, 0,6\% w Niemczech, 0,7\% w Wielkiej Brytanii do 5,3\% w Hongkongu [7-9], a w krajach Ameryki Północnej - między 0,3\% a 3,5\% [10]. Z kolei w Australii problemy z graniem miało 2,3\% dorosłych [11]. W Polsce objawy zaburzeń hazardowych występowały u ponad $5 \%$ respondentów w 15 . roku życia i powyżej - prawie $4 \% \mathrm{z}$ nich przejawiało niski poziom zaburzeń, $0,7 \%$ średni, u $0,7 \%$ badanych rozpoznano syndromy hazardu problemowego [12].

Wiele badań pokazuje, że tylko nieliczni spośród tych, którym postawiono diagnozę zaburzeń hazardowych, decydują się na podjęcie leczenia bądź uczestniczenie w mityngach Anonimowych Hazardzistów [13, 14]. W Stanach Zjednoczonych tylko 7,1-9,9\% osób z zaburzeniami hazardowymi poszukiwało profesjonalnej pomocy $[15,16]$. W Ontario, w Kanadzie, 10\% problemowych hazardzistów i $29 \%$ patologicznych hazardzistów podejmowało leczenie bądź uczęszczało na spotkania Anonimowych Hazardzistów [17]. Podobne wyniki otrzymano $\mathrm{w}$ badaniach prowadzonych $\mathrm{w}$ krajach $\mathrm{z}$ rejonu Pacyfiku. W Australii profesjonalnej pomocy poszukiwało 23\% osób doświadczających problemów wynikających z grania i 7\% osób z mniej nasilonymi problemami [18], a w Nowej Zelandii - 10-15\% osób z zaburzeniami hazardowymi [19].

Niewielka wiedza o zaburzeniach hazardowych w społeczeństwie i postrzeganie hazardu w kategoriach moralnych, a nie medycznych ma wpływ na społeczną akceptację dla takich zachowań i może determinować sposób radzenia sobie z problemami: samodzielne radzenie sobie zamiast korzystania ze specjalistycznej pomocy [2, 4, 20-22]. Oprócz tego do niepodejmowania leczenia mogą przyczyniać się różne czynniki - społeczne, kulturowe, indywidualne i związane ze strukturą systemu pomocy $[11,23$, 24]. Podobnie jak w przypadku większości innych uzależnień, lecznictwo jest najbardziej kosztowną odpowiedzią na problemy, jakie rodzą używanie 
to improve the medical system and also introduce solutions that allow for an improvement in the quality of service offered.

The purpose of the article is to present recommendations for an improvement in the service provision situation for persons with gambling disorders and the adaptation of services to their needs.

\section{- Material AND methods}

\section{Study project aims}

The study was conducted as part of the "Availability of treatment for problem and pathological gamblers in Warsaw" project on behalf of the National Bureau for Drug Prevention. The main aim was, as the name suggests, the analysis of treatment availability for persons with gambling disorders. The particular aims of the study included:

- evaluation of the existing offer available for persons with gambling disorders,

- assessment of the perception of persons with gambling disorders by medical personnel and employees of social welfare centres,

- identification of barriers and improvements in access to facilities,

- recognising the experiences of these persons in their contact with treatment.

\section{Sample selection}

The selection of participants for qualitative interview was in the form of purposive sampling, which means that respondents were qualified to the sample if they, according to the researchers, were capable of supplying full and exhaustive information from the point of view of the study aims. The researchers therefore selected participants on the basis of general familiarity with the studied phenomenon [25].

Research participants included persons with gambling disorders, social welfare centre personnel, therapists employed in addiction treatment centres (both for persons dependent on drugs and alcohol), general practitioners employed in primary health centres and psychiatrists.

The studied sample was 90 respondents. Researchers conducted 30 interviews with persons with gambling disorders and 15 interviews with each of the professional groups - the social welfare substancji oraz inne uzależnienia behawioralne. Stąd konieczność podejmowania działań usprawniających system leczenia, jak również wprowadzenia rozwiązań, które pozwolą na poprawę jakości świadczonej pomocy.

Celem artykułu jest przedstawienie rekomendacji dla poprawy sytuacji w zakresie świadczenia pomocy osobom z zaburzeniami hazardowymi i dostosowania oferty do ich potrzeb.

\section{- Materiat I metody}

\section{Cele projektu badawczego}

Badania prowadzono w ramach projektu „Dostępność leczenia dla problemowych i patologicznych hazardzistów w Warszawie", realizowanego na zlecenie Krajowego Biura ds. Przeciwdziałania Narkomanii. Głównym ich celem była, jak sama nazwa wskazuje, analiza dostępności leczenia dla osób z zaburzeniami hazardowymi. Szczegółowe cele badania obejmowały:

- ocenę istniejącej oferty pomocy dla osób z zaburzeniami hazardowymi,

- ocenę postrzegania osób z zaburzeniami hazardowymi przez personel medyczny i pracowników ośrodków pomocy społecznej,

- zidentyfikowanie barier i ułatwień w dostępie do placówek,

- poznanie doświadczeń tych osób w ich kontaktach z lecznictwem.

\section{Dobór próby}

Dobór uczestników do realizacji wywiadów jakościowych był celowy (purposive sampling), co oznaczało, że do próby kwalifikowano respondentów, którzy według badacza mogli dostarczyć pełnych i wyczerpujących informacji z punktu widzenia postawionych celów badania. Prowadzący dobierał zatem uczestników na podstawie ogólnej znajomości badanego zjawiska [25].

W badaniach wzięły udział osoby z zaburzeniami hazardowymi, pracownicy ośrodków pomocy społecznej (OPS), terapeuci zatrudnieni w placówkach leczenia uzależnień (zarówno dla osób uzależnionych od narkotyków, jak i od alkoholu), lekarze zatrudnieni w placówkach podstawowej opieki zdrowotnej (POZ) i lekarze psychiatrzy.

Badana próba liczyła 90 respondentów. Przeprowadzono 30 wywiadów z osobami z zaburzeniami hazardowymi oraz po 15 wywiadów w każdej gru- 
centre workers, the therapists employed in addiction treatment centres, general practitioners and psychiatrists.

Criteria for study inclusion was status as a institution employee and profession while in the case of persons with gambling disorders this was diagnosed disorder confirmed by a psychiatrist.

Persons with gambling disorders were recruited at addiction treatment centres for alcohol and drugs with the aid of therapists who gained participants' consent in personal contacts and during meetings in which the researcher gained the consent of Gamblers Anonymous group leaders to pass on invitations to take part in the study. Interested persons contacted the interviewers to arrange the details of the interview meetings.

\section{Studied person characteristics}

The clear majority in the group of persons with gambling disorders was male. Only three women took part in the study. The average age of the patients was 38 ( $\mathrm{SD}=10.827$, median 36 years), the youngest was 25 and the oldest 63 . The clear majority of the subjects lived in Warsaw and 8 respondents outside the city. More than half the gambling disorder group $(n=18)$ had higher education (bachelor's or master's degree), almost 1 in $3(n=9)$ had middle education and 1 in $10(n=3)$ vocational. There were no participants with basic or pre-high school education. Almost all had regular sources of income, two thirds $(n=20)$ were in full time employment, while one quarter $(n=7)$ were self-employed and 2 had pensions or benefits. Only one person was unemployed.

Slot machine players and casino goers dominated the gambling disorder group. Almost 1 in 2 of the respondents $(n=13)$ took advantage of the Internet. The same $(n=13)$ proportion played cards for money outside the casino or Internet. SMS lotteries were less popular, as were horse or dog races and betting shops.

The professionals group was dominated by women, who made up three quarters of the sample $(n=42)$. The average age was $43(\mathrm{SD}=12.012$ and median 40 years) and varied depending on the professional group - the youngest were the therapists and the oldest the psychiatrists. The clear majori- pie profesjonalistów - z pracownikami OPS, terapeutami zatrudnionymi w placówkach leczenia uzależnień, lekarzami z placówek POZ i lekarzami psychiatrami.

Kryteriami włączenia do badania dla profesjonalistów był status pracownika instytucji i wykonywany zawód, w przypadku osób z zaburzeniami hazardowymi - diagnoza zaburzenia potwierdzona przez lekarza psychiatrę.

Osoby z zaburzeniami hazardowymi były rekrutowane w placówkach leczenia uzależnień od alkoholu i narkotyków za pośrednictwem terapeutów, którzy w kontakcie indywidualnym uzyskiwali zgodę na udział w badaniu, oraz podczas mityngów - ankieter zwracał się do lidera grupy Anonimowych Hazardzistów z prośbą o przekazanie zaproszenia do udziału w badaniu. Osoby zainteresowane kontaktowały się $\mathrm{z}$ realizatorami wywiadów w celu ustalenia szczegółów spotkania.

\section{Charakterystyka badanej próby}

Zdecydowaną większość w grupie osób z zaburzeniami hazardowymi stanowili mężczyźni. $\mathrm{W}$ badaniu wzięły udział jedynie trzy kobiety. Średni wiek pacjentów wynosił 38 lat ( $\mathrm{SD}=10,827$; mediana 36 lat), najmłodszy miał 25 lat, najstarszy - 63 lata. Zdecydowana większość badanych mieszkała w Warszawie, 8 respondentów - poza Warszawą. Więcej niż połowa osób z zaburzeniami hazardowymi $(n=18)$ miała wykształcenie wyższe (licencjackie lub magisterskie), prawie co trzecia $(n=9)$ - średnie, a co dziesiąta $(n=3)$ - zawodowe. W badaniu nie uczestniczyły osoby $\mathrm{z}$ wykształceniem podstawowym i gimnazjalnym. Prawie wszyscy mieli regularne źródło dochodów, dwie trzecie osób $(n=20)$ było zatrudnionych $\mathrm{w}$ pełnym wymiarze godzin, prawie jedna czwarta $(n=7)$ prowadziła własną działalność gospodarczą, a 2 osoby pobierały emeryturę bądź rentę. Tylko jedna osoba była bezrobotna.

Wśród osób z zaburzeniami hazardowymi dominowali gracze na automatach oraz $\mathrm{w}$ kasynach. Prawie co drugi respondent $(n=13)$ do grania wykorzystywał Internet. Taki sam odsetek $(n=13)$ badanych grał w karty na pieniądze poza kasynem i Internetem. Mniej popularnymi grami były loterie SMS, wyścigi koni lub psów oraz zakłady wzajemne realizowane w punktach bukmacherskich.

Grupa profesjonalistów była zdominowana przez kobiety, które stanowiły trzy czwarte próby $(n=42)$. Średni wiek wynosił 43 lata $(S D=12,012$; mediana 40 lat) i wahał się w zależności od grupy 
ty lived in Warsaw with only a few people outside the city.

\section{Study tools}

Three interview guidelines were prepared - for gambling disorder persons, for the social workers and for professionals employed in the health services; that is primary health care GPs, psychiatrists and therapists.

The gambling disorder interviews were divided into six parts: experiences associated with seeking help (reasons for starting treatment, circumstances of becoming aware of the problem, seeking aid beyond the medical services, reasons for choice of centre and difficulties in gaining support), assessment of treatment availability (positive and negative experiences of treatment), perception of persons with gambling disorders on the basis of own experience, recommendation as regards improving the state of medical treatment, type of gambling practiced and matters concerning comorbidity of gambling and mental disorders.

The interview guidelines for the social workers included questions concerning the reasons aid was sought on the social welfare centres by persons with gambling disorders, the help they were offered, the perception of persons with gambling disorders by social workers and recommendations for improving the situation.

In the interview guidelines for the general practitioners, psychiatrists and therapists, the matter of causes and circumstances for undertaking treatment by gambling disorder persons was raised. As was the availability and possibility of treatment and gaining support, stigmatisation of such persons and recommendations concerning the improvement of the medical service.

All the interview guidelines contained a rubric allowing the collection of basic sociodemographic data like age, gender, place of residence, marital status, education and employment.

\section{Study protocol and data analysis}

The interviews were conducted in the first half of 2015 with the face-to-face method. The research was preceded by a pilot study. In this phase there were ten interviews carried out, two in each study group. Following the pilot studies, several minor changes to the interview guidelines were made. The pilot interviews were included in the analysis. profesjonalistów - najmłodsi byli terapeuci, najstarsi psychiatrzy. Zdecydowana większość osób mieszkała w Warszawie, jedynie kilka osób poza miastem.

\section{Narzędzia badawcze}

Przygotowano trzy rodzaje dyspozycji do wywiadów - dla osób z zaburzeniami hazardowymi, dla pracowników socjalnych oraz dla profesjonalistów zatrudnionych w sektorze ochrony zdrowia, tj. lekarzy podstawowej opieki zdrowotnej, lekarzy psychiatrów oraz terapeutów.

Dyspozycje do wywiadów z osobami z zaburzeniami hazardowymi były podzielone na sześć sekcji: doświadczenia związane z poszukiwaniem pomocy (powody podjęcia leczenia, okoliczności uświadomienia sobie problemu, poszukiwanie pomocy poza lecznictwem, powody wyboru placówki, trudności z uzyskaniem pomocy), ocena dostępności leczenia (pozytywne i negatywne doświadczenia dotyczące leczenia), postrzeganie osób z zaburzeniami hazardowymi na podstawie własnych doświadczeń, rekomendacje odnoszące się do poprawy sytuacji w lecznictwie, rodzaje uprawianego hazardu oraz kwestie związane ze współwystępowaniem zaburzeń psychicznych.

W dyspozycjach dla pracowników socjalnych znalazły się pytania dotyczące powodów poszukiwania pomocy w ośrodkach pomocy społecznej przez osoby z zaburzeniami hazardowymi, oferty pomocy dla nich, postrzegania osób z zaburzeniami hazardowymi przez pracowników socjalnych i rekomendacji w sprawie poprawy sytuacji.

W dyspozycjach przeznaczonych dla lekarzy podstawowej opieki zdrowotnej, lekarzy psychiatrów i terapeutów poruszono kwestie przyczyn i okoliczności podejmowania leczenia przez osoby z zaburzeniami hazardowymi, dostępności i możliwości uzyskania pomocy, stygmatyzacji tych osób oraz rekomendacji odnoszących do poprawy oferty medycznej.

Wszystkie rodzaje dyspozycji do wywiadów zawierały metryczkę pozwalającą na zebranie podstawowych danych socjodemograficznych, takich jak wiek, płeć, miejsce zamieszkania, stan cywilny, wykształcenie, zatrudnienie.

\section{Protokół badania i analiza danych}

Wywiady były prowadzone $\mathrm{w}$ pierwszej połowie 2015 roku metodą face-to-face („twarzą w twarz”). Badania właściwe zostały poprzedzone pilotażem. W tej fazie przeprowadzono dziesięć wywiadów, po dwa w każdej grupie badanych. Po realizacji badań pi- 
Each interview was analysed separately by two independent researchers. The first stage was reading the whole text and making margin notes that formed the code. Next the number of codes was limited to those that were interesting from the perspective of the set study aims. In the second stage of the analysis, the codes were aggregated to appropriate subject categories, and the latter were aggregated to analytical parameters making up wider categories.

Interview analysis was conducted in the traditional method and no computer programmes were employed.

\section{Ethical issues}

Permission for the study was gained from the Bioethics Committee at the Institute of Psychiatry and Neurology in Warsaw.

The study was anonymous and participation voluntary. The respondents did not receive remuneration. Their replies were marked only with a number and no personal data was gathered.

Prior to joining the study, respondents were specifically informed as to its aims, of their anonymity and reassured of the confidentiality of the gathered information. Participants signed informed consent to taking part in the study was a condition of inclusion.

\section{- Results}

The recommendations identified in the study can be qualified into five areas:

1) limiting the availability of gambling,

2) information and education,

3) increasing access to treatment,

4) improving the quality and adequacy of treatment,

5) scientific research.

\section{Limiting availability}

Among the recommendations regarding the limitation of availability was reducing the possibility of gambling activity, especially the access to slot machines and Internet gambling, introduction of opening-time limitations for gambling points and the introduction and execution of a ban on underage gambling.

Even though the number of slot machines has been falling over the last few years, their accessibility is still significant, especially as points are often open around the clock. lotażowych dyspozycje uległy niewielkim zmianom. Wywiady pilotażowe zostały włączone do analizy.

Każdy wywiad analizowało oddzielnie dwóch niezależnych badaczy. Pierwszym etapem było przeczytanie całego tekstu i zrobienie na marginesie notatek, które stanowiły kody. Następnie ograniczono liczbę kodów do tych, które były interesujące z perspektywy założonych celów badania. W drugim etapie analizy zagregowano kody do odpowiadających im kategorii tematycznych, a te ostatnie z kolei zagregowano do wymiarów analitycznych stanowiących szersze kategorie.

Analizę wywiadów prowadzono metodą tradycyjną, nie korzystano z żadnego oprogramowania.

\section{Kwestie etyczne}

Na realizację badania uzyskano zgodę Komisji Bioetycznej działającej przy Instytucie Psychiatrii i Neurologii w Warszawie.

Badanie było anonimowe, a uczestnictwo w nim dobrowolne. Respondenci nie otrzymywali wynagrodzenia. Ich wypowiedzi oznaczano jedynie numerem, nie zbierano danych osobowych.

Przed przystąpieniem do badania respondenci byli szczegółowo informowani o jego celach, o anonimowości i zapewnieni o poufności zbieranych informacji. Warunkiem uczestnictwa w badaniu było podpisanie świadomej zgody na udział w nim.

\section{- WYNIKI}

Zidentyfikowane w badaniu rekomendacje można zakwalifikować do pięciu obszarów:

1) ograniczanie dostępności hazardu,

2) informacja i edukacja,

3) zwiększanie dostępności leczenia,

4) poprawa jakości i adekwatności leczenia,

5) badania naukowe.

\section{Ograniczanie dostępności}

Wśród rekomendacji odnoszących się do ograniczenia dostępności badani wyróżnili zmniejszenie możliwości uprawiania hazardu, a zwłaszcza dostępu do automatów do gry i hazardu w Internecie, wprowadzenie ograniczeń co do godzin otwarcia punktów uprawiania hazardu oraz wprowadzenie i egzekwowanie zakazu uprawiania hazardu przez niepełnoletnich.

Mimo że liczba automatów do gier od kilku lat maleje, to jednak ich dostępność jest ciągle znaczna, zwłaszcza że są czynne często przez 24 godziny. 
Access to gambling is actually everywhere. There are machines pretty much everywhere. (H1605M1 $\left.{ }^{1}\right)$

There has been this recent witch hunt on the machines and they were going to be closed down. They still function and will carry on functioning as someone is making a fortune out of it and of course everyone knows you don't kill the cash cow. (H2703M1)

In the interviews with gambling disorder persons there is a ban postulated on gambling by the under aged.

I started to gamble when I was 16 and it was catastrophic. It would be better if it were not available for those who should not have access and access is incredible also because of the Internet. (H3003M2)

General practitioners also postulate limitation.

It's necessary to regulate access to gambling by legislation somehow. (POZ1604K2)

\section{Information and education}

Among the recommendations concerning information on the subject of problem of gambling and education, it was possible to identify those that relate to mass media campaigns, school education and warning information in gambling sites. Most of the proposals related to mass media campaigns. These most often came from persons with gambling disorders. They were of the opinion that the problem was under amplified and so not well recognised enough socially.

The problem certainly could be more publicised because it is so repressed (...) you have to go searching for it on the Internet. (H1805M1)

The problem ought to be better publicised. Because as far as gambling is concerned, the problem is certainly less widespread than for example alcoholism or drug addiction. (H2703M1)

Social campaigns about the existence of the problem. And it certainly ought to be done in such a way as to not scare people off or create an atmosphere of silliness. (H3103M1)

These people also saw the need to start education on the risk of gambling addiction already in school.

I had absolutely no chance to talk to anyone about this in school. There is no prophylactic in this respect and even when my friends knew

\footnotetext{
${ }^{1}$ Codification: TR - therapist, $\mathrm{H}$ - person with gambling disorder, POZ - GPs in primary health services, PS - psychiatrist, OPS - social welfare centre employee; XXXX - interview number; $\mathrm{M}$ - male, $\mathrm{K}$ - female; $\mathrm{Y}$ - number of interview carried out on the same day.
}

Naprawdę dostęp do hazardu jest wszędzie. Mamy dostęp, prawie wszędzie stoja maszyny. (H1605M1²)

Ostatnio była nagonka na maszyny, że pozamykane będa. Dalej funkcjonuja i będa funkcjonować, bo ktoś na tym zarabia krocie pieniędzy i wiadomo, że dojnej krowy się nie zabija. (H2703M1)

$\mathrm{W}$ wywiadach $\mathrm{z}$ osobami $\mathrm{z}$ zaburzeniami hazardowymi pojawia się postulat zakazu uprawiania hazardu przez niepełnoletnich.

Ja zaczałem grać, jak miałem 16 lat, $i$ to była katastrofa. Lepiej żeby to było niedostępne dla osób, dla których to ma być niedostępne, a dostępność jest niesamowita też dzięki temu, że jest Internet. (H3003M2)

Ograniczenia postulują też lekarze podstawowej opieki zdrowotnej.

Utrudnić dostęp do hazardu, jakoś ustawowo. (POZ1604K2)

\section{Informacja i edukacja}

Wśród rekomendacji dotyczących informacji na temat problemu hazardowego i edukacji w tym obszarze można było zidentyfikować te, które odnoszą się do kampanii prowadzonych w środkach masowego przekazu, edukacji szkolnej i informacji ostrzegawczych w miejscach uprawiania hazardu. Najwięcej propozycji odnosiło się do kampanii prowadzonych w środkach masowego przekazu. Najczęściej pochodziły one od osób z zaburzeniami hazardowymi. Uważały one, że problem jest za mało nagłośniony, a przez to słabo rozpoznany społecznie.

Na pewno mógłby być bardziej rozgłoszony ten problem, bo on jest tak sttumiony (...) trzeba się po stronach internetowych dowiadywać. (H1805M1)

Większe nagłośnienie tego problemu. Bo jeżeli chodzi o hazard, to na pewno problem jest duzo mniej rozpowszechniony niż na przykład alkoholizm czy narkomania. (H2703M1)

Kampania społeczna, że takie problemy występuja. I to powinno być na pewno w taki sposób zrobione, żeby nie odstraszać i nie wytworzyć atmosfery śmieszności. (H3103M1)

Osoby te widziały również potrzebę rozpoczęcia już w szkole edukacji na temat zagrożenia uzależnieniem od hazardu.

W ogóle nie było szans, żebym miał osobę, $z$ którą mógłbym w szkole o tym porozmawiać. Nie ma

\footnotetext{
${ }^{1}$ Sposób kodowania: TR - terapeuta, $\mathrm{H}$ - osoba z zaburzeniami hazardowymi, POZ - lekarz podstawowej opieki zdrowotnej, PS - lekarz psychiatra, OPS - pracownik ośrodka pomocy społecznej; XXXX - numer wywiadu; M - mężczyzna, K - kobieta; $\mathrm{Y}$ - numer wywiadu przeprowadzonego tego samego dnia.
} 
I gamble, nobody had a clue what to do about it. (H3003M2)

I think that this [education - auth.] ought to be in schools from a young age. I think that this information on drugs, gambling or alcohol would be useful. (H2703M1)

Therapists also spoke of the need for school education.

There ought to be more of this kind of information in schools so that people became aware before the problem starts, and more people would seek help before they became dependent. (TR2703M2)

We ought to be thinking about getting through to the schools and playschools even. So that the young person would see the warning signals. I'm thinking of above all some education, some information so it didn't get to the dependency. (TR2703M2)

Respondents with gambling disorders recommended placing warning notices in sites where gambling takes place.

Since we have health warnings on packets of cigarettes, then in each of these places or casinos there ought to be warnings of the same proportion. Like "being here may cause gambling dependency». And it ought to be in big letters, like we have it on the cigarette packs. (H1704M2)

\section{Increasing access to treatment}

From among the recommendations regarding the access to treatment it is possible to distinguish the increase in the number of programmes for persons with gambling disorders, reducing waiting times for treatment, improving information on the possibility of treatment, referral for treatment by general practitioners and medical specialists and insuring the possibility of treatment harmonised with professional duties.

Basically all the groups of respondents, includes both persons suffering from gambling related disorders and doctors and therapists, are aware of the need for new specialised programmes or centres.

Like I said it's a matter of the creation of new points, centres and more money directed to the centres. (H0806M1)

The postulations of psychiatrists are more specific.

More sites, more accessibility, more information and the opposite order of events. There should be more emphasis on problem awareness, describing what it is and the possibility of activity with a greater takiej profilaktyki $w$ tym względzie i nawet jak moi znajomi wiedzieli, że gram, to nikt nie miał pojęcia, jak się w związku $z$ tym zachować. (H3003M2)

Myślę, że już to [edukację - aut.] powinno się $w$ szkole od małego prowadzić. Myślę, że takie informacje, jeżeli chodzi o narkotyki, hazard czy alkohol, by się przydały. (H2703M1)

O potrzebie edukacji szkolnej mówili też terapeuci.

Więcej może jakiś takich informacji w szkołach. Żeby ludzie mieli świadomość, zanim wpadna w problem, żeby właśnie coraz więcej ludzi się zgłaszało jeszcze nieuzależnionych. (TR2703M2)

Trzeba byłoby pomyśleć o dotarciu do szkót, do przedszkoli już nawet. Żeby jakieś sygnały ostrzegawcze taki młody człowiek widział, miat wiedze na temat sygnałów ostrzegawczych. Więc myślę tutaj przede wszystkim o jakiejś edukacji, informacji, żeby nie doszło do uzależnienia. (TR2703M2)

Badani z zaburzeniami hazardowymi rekomendowali umieszczanie napisów ostrzegawczych w miejscach uprawiania hazardu.

Skoro na paczce papierosów jest napisane, że szkodliwe, no to na każdym takim salonie, kasynie powinno być $w$ takiej samej proporcji napisane, że «bycie tutaj może spowodować uzależnienie od hazardu». Ale to ma być wołami, tak jak my czytamy na papierosach. (H1704M2)

\section{Zwiększenie dostępności leczenia}

Wśród rekomendacji odnoszących się do dostępności leczenia można wyróżnić zwiększenie liczby programów dla osób z zaburzeniami hazardowymi, skrócenie czasu oczekiwania na leczenie, poprawę informacji na temat możliwości leczenia, kierowanie do leczenia przez lekarzy podstawowej opieki zdrowotnej i lekarzy specjalistów oraz zapewnienie możliwości leczenia bez kolizji z obowiązkami zawodowymi.

Potrzebę powstawania nowych wyspecjalizowanych programów lub ośrodków widzą w zasadzie wszystkie grupy respondentów - zarówno osoby cierpiące $\mathrm{z}$ powodu zaburzeń związanych $\mathrm{z}$ hazardem, jak i lekarze i terapeuci.

To tak jak mówiłem to jest kwestia powstania nowych punktów, ośrodków, więcej takich ośrodków, więcej pieniędzy skierowanych na te ośrodki. (H0806M1)

Bardziej konkretne są tutaj postulaty lekarzy psychiatrów.

Więcej placówek, większa dostępność, większa wiedza, kolejność odwrotna. Na zasadzie uświadomienia problemu, pokazania, czym jest ten problem, i możliwości działań przy większej dostępności tera- 
availability of therapists and centres perhaps within the National Insurance system. Because (...) accessibility, for example in private centres does seem to be sufficient. Waiting times are shorter there, though there may be a problem with financing. (PS2804M2)

It's a good idea to get out of the hospital a bit and run in outpatient clinics programmes focussing on a given problem and increasing the scope of service. (PS2801K2)

One of the psychiatrists proposes including gambling therapy in the list of guaranteed services.

There ought to inclusion in the basket of guaranteed services. There should be created a platform to contract this kind of service in separate facilities and not so that gambling is attached to any old dependency or other. If there were a model of this kind of facility and a form plus positive experience then maybe they would take root quicker and appear in our reality. (PS2805M1)

Therapists showed the most awareness that long waiting times may mean patients giving up on therapy.

It is important for this kind of patient that there is a short appointment waiting time because today the motivation to undertake therapy is there (...) while tomorrow it may be a completely different picture, so here time is of the essence. It ought to be quite quick so the motivation is not lost. (TR0705K1)

Apart from the physical availability of treatment, access to information on the treatment is of key importance. Above all, the patients see the need for information of this kind despite all having experience of treatment and so have at least found themselves in the medical centre. This information ought to be available in the mass media, the Internet and also in the sites where gambling takes place.

If, when gambling, I'd Google «dependency therapy» and get 50 clinics (...) then maybe I would sign up to a state one, as I'd know about it. (...) But I didn't know about it because it doesn't come up on the first page in the Internet. These days what counts is (...) what's on the first page of a Google search. (H2404M2)

It seems to me that there ought to be this kind of information [where you can get help with gambling - auth.] in casinos, because if you go on some foreign bookie services you always get a text at the bottom that you have made a conscious choice to gamble and there are links just in case you need help. However, if you go into a casino, peutów i ośrodków, może w ramach NFZ. Bo (...) dostępność, na przykład w poradniach prywatnych, wydaje mi się jest. Tam jest krótszy okres oczekiwania, natomiast problem z finansowaniem może być. (PS2804M2)

Wyjść trochę ze szpitala $i$ w poradniach prowadzić takie grupy skoncentrowane na danym problemie i zwiększyć tę ofertę poradniana. (PS2801K2)

Jeden $\mathrm{z}$ psychiatrów proponuje umieszczenie terapii dla hazardzistów w wykazie świadczeń gwarantowanych.

Wyodrębnienie w wykazie świadczeń, w ramach koszyka świadczeń gwarantowanych. Żeby stworzyć taka platformę do kontraktowania tego typu świadczeń $w$ osobnych placówkach, a nie żeby hazard byt przypięty do uzależnień takich, siakich czy owakich. Gdyby byt stworzony model tego typu placówek i forma plus pozytywne doświadczenie, to może one szybciej by się ukorzenity i pojawiły $w$ naszej rzeczywistości. (PS2805M1)

Terapeuci najlepiej sobie zdają sprawę, że długi czas oczekiwania może oznaczać rezygnację z podjęcia terapii.

To, co jest ważne dla takiego pacjenta, to to, żeby dostał szybki termin spotkania, bo dzisiaj jest zmotywowany do tego, by podjać leczenie (...) jutro już może to zupetnie inaczej wyglądać, więc tutaj czas jest ważny. Ważne, żeby to było dosyć szybko, żeby on nie stracit motywacji. (TR0705K1)

Oprócz fizycznej dostępności leczenia, kluczową rolę odgrywa jednak zapewnienie dostępu do informacji o leczeniu. Potrzebę taką widzą przede wszystkim sami pacjenci, mimo że wszyscy mają za sobą doświadczenia z leczeniem, a więc znaleźli drogę do placówki. Informacja taka powinna być dostępna w środkach masowego przekazu, w Internecie, ale także w miejscach uprawiania hazardu.

Gdybym grajac wpisat w Google «terapia do spraw uzależnień» czy «terapia uzależnień»i wyskoczyłoby mi 50 klinik (...) to bym może się zapisał do państwowej, bo bym o tym wiedział. (...) A nie wiedziałem o tym, bo w Internecie nie wyskakuje to na pierwszej stronie. W dzisiejszych czasach liczy się to, co (...) jest na pierwszej stronie w Google. (H2404M2)

Wydaje mi się, że w kasynach powinny być takie informacje [gdzie można uzyskać pomoc w związku z graniem - aut.], bo jeżeli wchodzimy na jakieś zagraniczne serwisy bukmacherskie, to zawsze na dole, $w$ stopce jest napisane, że zgadzasz się na świadoma gre, tam $w$ razie czego sa linki, gdzie szukać pomocy. Natomiast jak się wchodzi do kasyna, 
there is no such information so there ought to be something before the entrance or over it with that kind of information. There ought to be legislation obliging casinos and games salons to display this. (H1505M4)

There ought to be information (...) as you enter these entertainment places that gambling is an illness and you can get help at this phone number, postal or email address. Because the moment I go into a casino I do not have this kind of information. (H1505M4)

Therapists draw attention not only to insufficient information in the media but above all a lack of sensitivity to gambling problems among other professions that not only fail to refer, but don't even inform of the possibility of treatment.

It doesn't matter if it is a psychologist, a psychiatrist or a GP or even a priest, what matters is there is a referral [to a medical facility - auth.] (TR1802K1)

[General practitioners - auth.] can use their authority to say there is a psychologist at our outpatient clinic and you can talk to him or you have to go to the psychiatrist. They should say that you need a psychologist or psychiatrist at all. (TR1802K1)

Readiness to provide information on the possibility of treatment is pressed by social welfare centre employees.

If there are information-consultation points in the area, then information ought to be available at a point of this kind on where aid may be sought or some list of centres where one can go with this kind of problem. (OPS1201K2)

The increased availability of treatment ought to allow for harmonisation with work duties.

It would be worthwhile to make the groups at weekend or in the evenings, but not only the day care ward. (TR1303K1)

\section{Improving the quality and adequacy of treatment}

Among the recommendations concerning the improvement of quality and adequacy of treatment, it is possible to distinguish areas related to training professionals who deal with gambling disorder problems, cooperation between various professions and institutions to ensure interdisciplinary support, provision of a minimum of competent service in primary health care, development of specialised programmes for those with gambling disorders including programmes for patients with comorbidity of gambling and to żadnej takiej informacji nie ma, więc albo przed wejściem, albo na przykład na wejściu powinna być taka informacja. Wydaje mi się, że powinno być droga ustawy zrobione tak, żeby kasyna czy salony gier miaty obowiazzek wystawiania tego. (H1505M4)

Jak się wchodzi do takich miejsc albo już na miejscu $w$ takich ośrodkach rozrywkowych (...) żeby byly jakieś informacje, że hazard jest choroba $i \dot{z} e$ pod tymi numerami albo pod tym adresem lub adresem mailowym uzyskasz pomoc. Bo w momencie, kiedy ja wchodze do kasyna, do salonu gier, ja takich informacji nie posiadam. (H1505M4)

Terapeuci zwracają uwagę nie tylko na niedostateczną informację w mediach, lecz przede wszystkim na brak wrażliwości na problemy hazardowe wśród osób innych profesji, które nie tylko nie kierują, ale nawet nie informują o możliwościach leczenia.

Czy to będzie lekarz, czy to będzie psycholog, czy lekarz psychiatra, czy lekarz pierwszego kontaktu czy ksiądz proboszcz, ktokolwiek, to jest ważne, żeby ten ktoś wysłał [do placówki - aut]. (TR1802K1)

[Lekarze POZ - aut.] moga już użć swojego autorytetu do tego, żeby powiedzieć: tu jest $w$ poradni psycholog, może pan $z$ nim porozmawiać albo do psychiatry musi pan pójść. Żeby oni w ogóle powiedzieli, że potrzeba psychologa albo psychiatry. (TR1802K1)

Gotowość do udzielania informacji na temat możliwości leczenia wyrażają pracownicy opieki społecznej.

Jeżeli sa punkty informacyjno-konsultacyjne na terenie dzielnicy, to $w$ takim punkcie powinna być dostępna informacja na temat, gdzie szukać pomocy, czy jakiś wykaz placówek, gdzie można się zgłosić z takiego rodzaju problemem. (OPS1201K2)

Zwiększając dostępność leczenia, powinno się zapewnić możliwość jego podjęcia w taki sposób, by nie kolidowało to $\mathrm{z}$ obowiązkami zawodowymi.

Warto by było, żeby to były grupy w weekendy i wieczorne, żeby to nie było na zasadzie tylko takiej oferty oddziału dziennego. (TR1303K1)

\section{Poprawa jakości i adekwatności leczenia}

Wśród rekomendacji dotyczących poprawy jakości i adekwatności leczenia można wyróżnić obszary odnoszące się do: szkolenia pracowników w zakresie zaburzeń hazardowych, współpracy między różnymi profesjonalistami i instytucjami, tak aby oferta pomocy była wielodyscyplinarna, zapewnienia minimalnej kompetentnej oferty w podstawowej opiece zdrowotnej, opracowania wyspecjalizowanych programów dla osób z zaburzeniami hazardowymi, 
psychoactive substance dependence, increasing the service for active gamblers (controlled gambling programmes, changes in gambling pattern), teaching financial management skills, providing therapy for families, participation self-help and social organisations in tackling gambling problems and the provision of post-therapeutic care.

\section{Employee training in gambling disorders}

Therapists declare a lack of the appropriate competences to carry out therapy on persons with gambling disorders. They indicate a dearth of training in this respect.

There is little training on the subject or training on dependencies of this kind at all. Some kind of lack of access. I think that even if there are any they are rather expensive. This often restricts therapists or centres. (TR0705K1)

There ought to be investment in specialists working in small towns to raise awareness of the problem, educate them a little and ensure the basic service is provided. (TR1802K1)

Respondents of all the studied groups underline the shortage of properly trained specialists. This is especially keenly felt by the patients themselves, according to whom professionals trained in treatment of substance dependence do not have sufficient competences and experience as far as gambling disorders are concerned.

I see that there are very few specialists in gambling like there are therapists in drug addiction and alcoholism. (...) If there was more access to therapists then I believe there would be more willing to undertake therapy. (H3103M1)

General practitioners also see the need for specialised training in gambling-related disorders.

I feel the lack in such formal training (...) a serious, specific programme. When a gambling dependent comes to me I can do this and that and I can propose him this and that. And there are these and those methods. (POZ0503K1)

I'm also missing treatment training, at least of the initial kind. What medication should I be prescribing before they reach the psychotherapist and start psychotherapy and before it starts working. There is a time lapse and they may need help straight away. (POZ0503K1)

As a doctor, I have not seen an offer for post-diploma training in exactly this subject. (POZ1604K2) w tym programów dla współwystępujących $\mathrm{z}$ hazardem uzależnień od substancji, poszerzenia oferty dla czynnych graczy (programy grania kontrolowanego, zmiana wzoru), uczenia umiejętności zarządzania finansami, zapewnienia terapii rodzinom, udziału ruchów samopomocowych i organizacji społecznych w rozwiązywaniu problemu hazardowego oraz zapewnienia opieki postterapeutycznej.

\section{Szkolenia pracowników w zakresie zaburzeń hazardowych}

Terapeuci deklarują brak odpowiednich kompetencji do prowadzenia terapii osób z zaburzeniami hazardowymi. Zauważają, że brakuje szkoleń w tym zakresie.

Mało jest szkoleń na ten temat. Szkoleń w ogóle o uzależnieniach tego typu. Jakaś taka mała dostępność. Myśle, że jeżeli nawet one sa, to płatne dosyć wysoko. To też ogranicza często terapeutów czy placówki. (TR0705K1)

Trzeba by było zainwestować w tych specjalistów, którzy pracuja w małych miejscowościach, $w$ ich szkolenia, po to, żeby ich otworzyć na ten problem, zeby trochę ich doedukować $i$ żeby ta podstawowa oferta była. (TR1802K1)

Niedostatek właściwie przygotowanych specjalistów podkreślają respondenci ze wszystkich badanych grup. Ich brak szczególnie dotkliwie odczuwają sami pacjenci, według których profesjonaliści przeszkoleni w zakresie uzależnienia od substancji nie mają dostatecznych kompetencji i doświadczenia, jeśli chodzi o zaburzenia związane $\mathrm{z}$ hazardem.

Ja widze, wiem teraz, że np. jest bardzo niewielu terapeutów specjalizujących się właśnie w kwestii hazardu. Owszem, w kwestii narkomanii, alkoholizmu sa ci terapeuci. (...) Gdyby byly większe możliwości dostępu do terapeutów, to myślę, że byłoby więcej chętnych. (H3103M1)

Potrzebę specjalistycznego szkolenia w zakresie zaburzeń związanych $\mathrm{z}$ hazardem mają również lekarze podstawowej opieki zdrowotnej.

Brakuje mi w takim szkoleniu formalnym (...) rzetelnego, konkretnego programu. Przychodzi do mnie uzależniony od hazardu, robię $z$ nim to $i$ to, moge mu zaproponować to i to, sa takie i takie metody. (POZ0503K1)

Brakuje mi też takiego szkolenia z zakresu leczenia, przynajmniej wstępnego. Co podać tym pacjentom, jakie leki, bo zanim dotra do psychoterapeuty, zanim zaczna psychoterapię, zanim ta psychotera- 
There have been suggestions as to the content of training and its evaluation. The trainings ought to be evidence based and not on the personal views of trainers. According to the professionals offering support, it is necessary to develop appropriate standards for providing support to persons with gambling disorders.

No doubt we need various kinds of training related to something called evidence based medicine. That is medicine based on facts and not personal views or modelling on theory or the belief that there ought to be more training. (PS2301M1)

Perhaps these trainings ought to be evaluated in some kind of way because at the moment they seem to come up in a spontaneous kind of way and nobody is directing it. Meanwhile, maybe there ought to be some sort of steering committee that e.g. recognises a certain minimum like (...) in the treatment of alcohol or other psychoactive substance dependent persons in which you give acceptance for these programmes that fulfil a certain minimal standard of treatment. No such standards of treatment have been developed, neither is there a system of training. One can say nobody has this under control. There ought to be a certain standard of this kind of service. (PS2301M1)

\section{Cooperation between various professionals} and institutions

A need for cooperation, especially between various institutions offering services, is particularly evident from the perspective of primary health care.

We have so little contact with other specialists so that there is a gap between family doctors with whom patients have the most contact, and psychiatrists and district psychologists or between family doctors and social welfare centres with which we are supposed to be cooperating. This lack is a complete and general, and if it were possible to somehow improve this, it would certainly by easier to direct people like this to centres and have the sense they are not being sent somewhere where their fate is pretty much unknown. (POZ1704K1)

Social welfare centre employees themselves speak of the necessity of including them in the cooperation.

Since there is an information-consultation point for our whole district, I think we could also take advantage of the place to provide (...) information to these persons [dependent on gambling - auth.] about the available care. What often happens is persons who regularly use a specific department pia przyniesie efekty, czas biegnie, a oni moga potrzebować pomocy od razu. (POZ0503K1)

Ja jako lekarz nie spotkałam się $z$ oferta $n p$. kształcenia podyplomowego dokładnie na ten temat. (POZ1604K2)

Pojawiają się również postulaty co do treści szkoleń i ich ewaluacji. Szkolenia powinny być oparte na wynikach badań naukowych, a nie na osobistych poglądach osób szkolących. Zdaniem profesjonalistów zajmujących się pomocą należy wypracować odpowiednie standardy świadczenia pomocy osobom z zaburzeniami hazardowymi.

Niewątpliwie różnego rodzaju szkolenia, ale oparte na tym, co sie nazywa evidence based medicine. To medycyna oparta na dowodach, a nie osobiste poglady czy wzorowanie się na jakimś innym modelu, przekonaniu, że powinno być więcej szkoleń. (PS2301M1)

Być może te szkolenia powinny podlegać pewnego rodzaju ewaluacji, bo na razie powstaja w sposób spontaniczny, nikt tym nie dyryguje. Natomiast może powinien być jakiś taki komitet sterujacy, który np. uznaje pewne minimum, tak jak (...) w leczeniu osób uzależnionych od alkoholu czy od innych substancji psychoaktywnych, że mniej więcej daje się akceptację, daje się to zielone światto dla tych programów, które spetniaja pewien minimalny standard leczenia. Takich standardów leczenia nie opracowano, nie opracowano systemu szkolenia. Można powiedzieć, że nikt nad tym kontroli nie ma. Czyli pewnego rodzaju standaryzacja takich ustug powinna istnieć. (PS2301M1)

\section{Współpraca między różnymi profesjonalistami i instytucjami}

Potrzebę współpracy, zwłaszcza współpracy między różnymi instytucjami świadczącymi pomoc, widać szczególnie z perspektywy podstawowej opieki zdrowotnej.

Mamy tak mało kontaktów $z$ innymi specjalistami, że tak naprawdę jest przepaść między lekarzami rodzinnymi, z którymi jednak pacjenci maja najwięcej kontaktu, a psychiatrami czy psychologami rejonowymi, czy między lekarzami rodzinnymi a ośrodkami pomocy społecznej, z którymi też niby powinniśmy wspótpracować. Nie ma tego kompletnie i generalnie, jeżeli udałoby się w jakiś sposób to poprawić, na pewno byłoby łatwiej, na przykład kierować takie osoby do placówki i mieć poczucie, że one nie sa wysyłane gdzieś, gdzie nie wiadomo, co się z nimi dzieje. (POZ1704K1)

O konieczności współpracy i włączenia do niej pracowników opieki społecznej mówią również sami jej przedstawiciele. 
at the district office are also persons who gain information at the information-consultation point on the subject of other forms of help available in the district. (OPS1201K2)

The provision of minimum competent service in primary health care

Primary health care general practitioners do not limit their activity to referring to specialists in gambling disorders. They would like to pay more attention to patients with gambling problems though they note a lack of time for this purpose.

[There is - auth.] a lack of time with the patient even though everyone has some skills. I see my patients need this contact - that in fact it is what they need most. Sometimes I'm the only person they can come to and talk certain things out. And I have to keep a discrete eye on the time aware of the fact that the next patient is waiting. They sense this and the effect is less good. (POZ0503K1)

Doctors propose that patients fill in a screening test prior to the visit that would save time and define what service is needed.

They could fill in a short, very simple survey (...) identifying those we need to talk to. A test of this kind would help us very much at the initial stage before the visit even for another reason [not connected with gambling - auth.]. (POZ1704K1)

If before they end up here on the couch they did this [screening - auth.] test, I'd know what to talk about. This would be helpful I think. (POZ1704K1)

Psychologists and psychotherapists would have an important role to play in primary health care. Also, in GPs' opinion there is a need for the participation of district nurses and social workers.

There is a lack of psychologists and therapists in primary health care. In my opinion there ought to be one in our team because it is to us that patients mainly come. (POZ0403K1)

I believe we ought to have the support of social workers, there ought to be more nurses specialised in certain areas and there ought to be a psychologist in the primary health care team. There are too few people specialised in this kind of problem as this does not concern just gambling but everything. (POZ0403K1)
Jako że jest punkt informacyjno-konsultacyjny dla naszej całej dzielnicy, więc myślę, że też można by było wykorzystać to miejsce, aby udzielać (...) informacji tym osobom [uzależnionym od hazardu - aut.] o dostępnej pomocy. Często jest tak, że osoby, które korzystaja $z$ pomocy konkretnego wydziatu przy urzędzie dzielnicy, to też sa osoby, które w punkcie informacyjno-konsultacyjnym uzyskuja informacje na temat innych form pomocy dostepnych na terenie dzielnicy. (OPS1201K2)

\section{Zapewnienie minimalnej kompetentnej oferty w podstawowej opiece zdrowotnej}

Lekarze podstawowej opieki zdrowotnej nie ograniczają swojej roli do kierowania do specjalistów zajmujących się zaburzeniami związanymi $\mathrm{z}$ hazardem. Chcieliby pacjentom $\mathrm{z}$ problemem hazardowym poświęcić więcej uwagi, choć jednocześnie dostrzegają ograniczenia czasowe.

Czasu [brakuje - aut.] oczywiście, czasu, żeby temu pacjentowi poświęcić, bo jakieś umiejętności każdy posiada. Ja widze po swoich pacjentach, że oni potrzebuja tego kontaktu, to im jest najbardziej potrzebne. Czasami jestem jedynym człowiekiem, do którego oni moga przyjść i po prostu się wygadać, pewne rzeczy wyjawić. A ja muszę patrzeć dyskretnie na zegarek i mieć świadomość, że tam czeka następny pacjent $i$ oni to czuja, i jest gorszy efekt. (POZ0503K1)

Lekarze proponują, by pacjenci przed wejściem do gabinetu wypełniali testy przesiewowe, co pozwoliłoby zaoszczędzić czas i ukierunkować świadczoną pomoc.

Takie osoby umiałyby wypetnić krótką, bardzo prosta ankiete (...) przesiewajaca te osoby, z którymi trzeba porozmawiać. Bardzo by pomógł ten test. $\mathrm{Na}$ etapie takim, zanim miałby wejść do gabinetu, nawet $z$ innego powodu [niezwiązanego $\mathrm{z}$ hazardem - aut.]. (POZ1704K1)

Zanim trafi tutaj do mnie na te kanapke, do gabinetu, to mógłby już ten test [przesiewowy - aut.] wypetnić, ja bym już wiedziała, o czym z pacjentem porozmawiać. Myśle, że to mogłoby być pomocne. (POZ1704K1)

Istotną rolę mieliby do odegrania psychologowie lub psychoterapeuci zatrudnieni w podstawowej opiece zdrowotnej. Potrzebny jest także, w opinii lekarzy, udział pielęgniarek środowiskowych i pracowników socjalnych.

Brakuje psychologa czy terapeuty w POZ, moim $z$ daniem on powinien być $w$ naszym zespole, bo do nas głównie pacjenci trafiają. (POZ0403K1) 
Development of specialised programmes

for persons with gambling disorders

and for persons with comorbidity

of gambling disorders and psychoactive

substance dependencies

The patients underlined the need for the development of specialised therapy programmes. Not every one felt at ease in groups for alcohol or drug dependent persons.

A programme for gamblers would really be appreciated. I have not found one. The one available somewhere [name of centre - auth.] is a bit, I'd say, universal. It's not that you can't get treatment on this basis, but in my opinion it would be very helpful if there existed the possibility of treatment in a 100\% gamblers' group. (H3003M2)

All-gambler groups would be a lot more effective than groups that combine alcohol, gambling and drug dependents. Even the therapists only go with reference to alcohol. (H1605M1)

According to therapists, this is not about the creation of new, specialised centres, but of specialised programmes realised at existing sites for addiction treatment and mental health outpatient clinics.

This [programme for treating gambling disorders - auth.] should be included in the service range of centres specialising in addiction or in mental health. In such a centre we could de-stigmatise this [gambling disorders - auth.] a little. (TR1802K1)

I would imagine that each outpatient clinic [for addiction - auth.] equally deals with gambling. (TR2704M1)

Therapists, just like patients, believed that therapeutic groups ought to be homogenous as regards the type of dependency as the experiences of persons dependent on substances and those on gambling often differ.

As far as possible gambler-only groups could be formed so they could all be together. (TR0705K1)

There is a lack, for example, of places where there would by groups exclusively for people dependent on gambling and not combined groups for any dependent person. Everyone is treated together like in one group, but perhaps it would be better if it would be separately? (TR2603K3)

Psychiatrists also believe that it is necessary to develop specialist outpatient programmes for persons affected by gambling problems.
Myślę, że powinniśmy mieć wsparcie pracowników socjalnych, powinno być więcej pielęgniarek wyspecjalizowanych $w$ danych zagadnieniach, powinien być psycholog $w$ zespole takiego POZ. Jest $z a$ mało osób wyspecjalizowanych $w$ takich problemach, bo to przecież nie dotyczy tylko hazardu, tylko wszystkiego. (POZ0403K1)

\section{Rozwój wyspecjalizowanych programów dla osób z zaburzeniami hazardowymi, w tym programów dla współwystępujacych uzależnień od substancji}

Pacjenci podkreślali potrzebę wypracowania wyspecjalizowanych programów terapii. Nie wszyscy czuli się dobrze w grupach dla uzależnionych od alkoholu czy narkotyków.

Przydałby się $w$ ogóle program leczenia hazardzistów. Ja się z takim nie spotkałem. Ten, z którego gdzieś tam [nazwa placówki - aut.] się korzysta, jest taki, bym powiedział, uniwersalny i to nie jest tak, że się nie da na jego podstawie leczyć, ale moim zdaniem bardzo byłoby przydatne, żeby istniała możliwość leczenia się w grupie samych hazardzistów. (H3003M2)

Grupy samych hazardzistów bylyby dużo bardziej skuteczne niż grupy, które łącza ze sobq alkoholika, hazardziste i narkomana. Bo nawet terapeuci ida tylko pod katem alkoholu. (H1605M1)

Według terapeutów nie chodzi tu o tworzenie nowych wyspecjalizowanych ośrodków, ale o specjalistyczne programy realizowane $\mathrm{w}$ istniejących placówkach leczenia uzależnień, a także w poradniach zdrowia psychicznego.

Żeby to [program leczenia zaburzeń hazardowych - aut.] weszło $w$ ogóle do oferty poradni zajmujacych się chorobami uzależnienia czy też zdrowia psychicznego. W takiej poradni troche można by to [zaburzenia hazardowe - aut.] odstygmatyzować. (TR1802K1)

Ja bym sobie wyobrażat, że po prostu każda poradnia [uzależnień - aut.] zajmuje się tak samo hazardem. (TR2704M1)

Podobnie jak pacjenci, również terapeuci uważali, że grupy terapeutyczne powinny być homogeniczne, jeśli chodzi o rodzaj uzależnienia, gdyż doświadczenia osób uzależnionych od substancji i osób z zaburzeniami hazardowymi są często odmienne.

$W$ miarę możliwości mogłyby być tworzone grupy dla hazardzistów tylko, żeby oni byli tylko razem. (TR0705K1) 
Such therapeutic, outpatient, every day advice or an outpatient programme is much easier to develop or create a small therapeutic group in some rehab clinic. So if you collect 5-6 gamblers, we could create a small group of and run it. In the outpatient centre this is easy but in a inpatient centre few would decide on profiling with respect to gambling. (PS2805M1)

In one of the statements there is the appearance of the idea of gradual commitment to therapy offers via the Internet through to individual consultations towards group work.

I'm thinking of some Internet form in which patients could anonymously declare problems and seek support. The Internet is their natural life and functioning environment. There they seek negative things so they could also find the constructive. That could perhaps be a start and then move up a level to individual consultations only then to be followed by group work. (PS2104M1)

One of the general practitioners suggests the creation of telephone information and consultation by which patients could gain immediate help rather than waiting weeks for an appointment at the specialists.

It would be a great help if there were some sort of initial consultation [over the phone auth.] and that the patient could receive a consulting point phone number. Or for example one line for each district where people like this could call and gain at least some kind of first contact. (POZ1704K1)

Increasing the service for active gamblers

(controlled gambling training programmes,

changes in gambling pattern)

The controversial question of harm reduction, the creation of alternative approaches to the total abstinence paradigm, appears almost only in the statements of therapists, the most experienced of the participating professionals in providing support to gambling disorder persons.

This kind of initial group for gamblers who have not given up gambling, but more of an educational group meant to demonstrate various mechanisms. What I'm missing in dependency as a whole is these groups that concentrate on process. (TR2702M1)

Harm reduction strategies could also include employees in the gambling sector who are sometimes trained in brief interventions.
Brakuje np. takich miejsc, gdzie by były grupy tylko i wyłąznie dla osób uzależnionych od hazardu, a nie połączone grupy dla osób w ogóle uzależnionych. Wszystkie osoby sa leczone razem, jakby $w$ jednej grupie, natomiast może byłoby lepiej, gdyby byly oddzielnie? (TR2603K3)

Lekarze psychiatrzy również uważają, że konieczne jest opracowanie specjalistycznych programów ambulatoryjnych dla osób dotkniętych problemami związanymi z hazardem.

Poradę terapeutyczna, taka ambulatoryjna, codzienna czy program ambulatoryjny jest znacznie łatwiej wykreować czy zrobić maleńka grupe terapeutyczna $w$ jakiejś poradni odwykowej. Więc to jest tak, że jak się zbierze 5-6 hazardzistów, to już moglibyśmy zrobić mała grupe i ja prowadzić. $W$ ambulatorium to łatwe, natomiast ośrodek stacjonarny mało który się zdecyduje na wyprofilowanie pod katem hazardu. (PS2805M1)

W jednej z wypowiedzi pojawia się koncepcja stopniowego angażowania $\mathrm{w}$ terapię - od oferty przez Internet przez indywidualne konsultacje do pracy w grupie.

Ja myśle o jakiejś formie internetowej, na której mogliby pacjenci anonimowo zgłaszać problemy, szukać pomocy. Internet to jest ich naturalne środowisko życia i funkcjonowania. Tam szukaja rzeczy negatywnych, moga szukać konstruktywnych. Od tego chyba można by było zaczać i potem przejść na poziom takich konsultacji indywidualnych, potem dopiero wejście do grupy. (PS2104M1)

Jeden z lekarzy podstawowej opieki zdrowotnej sugeruje stworzenie telefonicznego systemu informacji i konsultacji, gdzie pacjenci mogliby otrzymać natychmiastową pomoc, a nie czekać tygodniami na wizytę u specjalisty.

Bardzo by pomogło, jakby był rodzaj przynajmniej takiej wstępnej konsultacji [telefonicznej aut.], żeby pacjentowi podać telefon do takich osób. Albo na przykład taki telefon dla danej dzielnicy, gdzie te osoby mogtyby zadzwonić i uzyskać przynajmniej jakiś pierwszy kontakt. (POZ1704K1)

\section{Poszerzenie oferty dla czynnych graczy \\ (programy nauki grania kontrolowanego, \\ zmiana wzoru grania)}

Kontrowersyjna kwestia redukcji szkód, stworzenie alternatywnych do paradygmatu abstynencyjnego podejść, pojawia się prawie wyłącznie w wypowiedziach terapeutów, najbardziej doświadczonych 
Last year I trained croupiers in casinos. They introduced various programmes of safe gambling so, among other things, there is this self-limitation system they decided on introducing. This is about the patient signing a written agreement declaring that during some period he is not to be let into the casino or be allowed to gamble or play the slot machines. This is also some kind of innovation and an opening as far as the Warsaw casinos are concerned. Generally, in the West, this is one of the stable programme fixtures like safe gambling or crisis intervention programmes in casinos - such a brief intervention is made so that they [the gamblers - auth.] find their way to the treatment system as long as they of course express consent. So that's the kind of croupier training I was doing but for the time-being it's still a long way for this to appear here on a wider scale. (TR0705K2)

\section{Financial management skills training}

One of the specific elements of gambling disorder therapy mentioned as missing in the available programmes is the matter of teaching money management and getting out of debt skills.

It's sort of the role of a person who helps you get out of debt. This is well developed in the UK. I don't know if there is anyone here at all who helps with getting out of debt. (...) I don't think there is the kind of person who would be doing this here. (TR1303K1)

Psychiatrists also see the need for creating this kind of programme. In their opinion, the therapeutic offer ought to include financial and legal advice. The lawyers ought to conduct negotiations with the creditors in the matter of debt in the name of patients.

The kind of comprehensive programmes that would include financial advice and legal aid that would for example negotiate debt restructuring with the banks so that the debt would be repaid (...) over a longer period with interest reduction and debt consolidation - all the things a normal person can't deal with, let alone a gambler. There is a lack of that kind of comprehensive programme. (PS2301M1)

\section{Ensuring family therapy}

Gambling, apart from hitting the budget, severely disrupts family relations. On the one hand, mutual trust disappears, and on the other, family spośród badanych profesjonalistów w udzielaniu pomocy osobom z zaburzeniami hazardowymi.

Taka grupe wstępna dla osób, np. dla hazardzistów, którzy nie rezygnuja z hazardu, ale bardziej taka grupe edukacyjna, majaca im pokazać różne mechanizmy. Czego w ogóle mi w uzależnieniach brakuje takich grup skoncentrowanych na procesie. (TR2702M1)

Strategie redukcji szkód mogą również włączać pracowników sektora gier hazardowych, którzy są czasami szkoleni do prowadzenia krótkich interwencji.

W ubiegłym roku szkoliłam krupierów $w$ kasynach. Oni wprowadzali różnego rodzaju programy bezpiecznej gry, więc m.in. też jest ten system samoutrudniania, który zdecydowali się wprowadzić. Polegajacy na tym, że pacjent sam deklaruje i podpisuje zgodę pisemna, że przez jakiś okres maja go nie wpuszczać do kasyna, nie pozwalać mu grać czy korzystać $z$ tych automatów lub ruletek. To też jest jakaś innowacją, otwartościa z ich strony, jeśli chodzi np. o warszawskie kasyno. Ogólnie na Zachodzie jest to jeden ze stałych programów, tak jak i program bezpiecznej gry czy program interwencji kryzysowej w kasynie - przeprowadza się taka brief intervention po to, żeby oni [gracze - aut.] trafili do systemu lecznictwa, o ile oczywiście wyraża na to zgodę. No to ja takie szkolenie krupierów robiłam, ale na razie jeszcze pewnie daleka droga do tego, żeby to u nas wdrożyć szerzej. (TR0705K2)

\section{Uczenie umiejętności zarządzania finansami}

Spośród specyficznych dla leczenia zaburzeń hazardowych elementów terapii, których brakuje w dostępnych programach, wymieniano kwestię uczenia umiejętności gospodarowania pieniędzmi oraz wychodzenia z długów.

Jakby taka funkcja osoby, która pomaga w wychodzeniu z długów. W Anglii jest to rozwinięte. Nie wiem, czy np. u nas $w$ ogóle sq takie osoby, które pomagaja $w$ wychodzeniu $z$ długów. (...) Chyba nie ma takich osób, które by się tym zajmowaty. (TR1303K1)

Potrzebę stworzenia takich programów również widzą lekarze psychiatrzy. W ich ocenie oferta terapeutyczna powinna uwzględniać doradztwo finansowe i prawne. Prawnicy powinni w imieniu pacjentów prowadzić $\mathrm{z}$ wierzycielami negocjacje w sprawie długów.

Absolutnie nieliczne sa takie programy kompleksowe, na które składałoby się doradztwo finansowe, 
members descend into co-dependency. According to respondents, the inclusion of the whole family in therapy is of key significance for its success. This view is expressed not only by gambling disorder persons themselves, but also by the psychiatrists.

I hadn't mentioned co-dependency but this is a mega important matter and a missing element very much absent from the treatment offer. It is also important from the point of view of the dependent persons that their close persons also have access to this treatment. (H3003M2)

The family, husband, wife and children of the patient have an enormous problem in all this. They are completely at a loss and don't know what to do. The matter of support, and therapy, like for example in the case of the families of alcohol dependents is important because they don't know what to do. (PS2804M2)

The kind of comprehensive support in the sense that it is not only about treating the symptoms but various life consequences associated with it. The family and the person's relations start to fall apart. Then not only the patient requires therapeutic support but the patient's whole family environment. (PS2104M1)

Involving self-help movements and social organisations in solving the gambling problems

The topic of self-help movements, especially Gamblers Anonymous, came up in the statements of many respondents representing patients and professionals. One of the social workers spoke more widely about the perspective of including these non-governmental organisations into the solution to the gambling problem.

It seems to me that with a structure of this kind and these legal possibilities, it would be best dealt with by non-governmental organisations. Some of which do the most wonderful things. It [a non-governmental organisation - auth.] is elastic, can react and sees the problems close up. (...) The centre [medical - auth.] as an institution is a matter of arranging which would take on the job. But the actual therapy or diagnosis, or the orientation, well that seems to me best suited to the non-governmental organisations. (OPS1002K1)

\section{Ensuring post-therapeutic offer}

People with gambling disorders signalled the need for post therapy care. Including people in therapy who are completing treatment could contribute pomoc prawników, którzy by np. negocjowali z bankami restrukturyzacje długu, rozkładanie (...) na dłuższe okresy, zmniejszanie odsetek, skonsolidowanie długów $i$ te wszystkie rzeczy, z którymi normalny człowiek nie jest sobie w stanie poradzić, a co dopiero hazardzista. Takich programów kompleksowych brakuje. (PS2301M1)

\section{Zapewnienie terapii rodzin}

Hazard, oprócz uszczuplenia budżetu, zaburza głęboko relacje $\mathrm{w}$ rodzinie. $\mathrm{Z}$ jednej strony znika wzajemne zaufanie, $\mathrm{z}$ drugiej - członkowie rodziny popadają we współuzależnienie. Według respondentów objęcie całej rodziny terapią ma kluczowe znaczenie dla jej powodzenia. Mówią o tym nie tylko same osoby z zaburzeniami hazardowymi, ale także psychiatrzy.

Jeśli chodzi o osoby współuzależnione, $w$ ogóle wcześniej o tym nie powiedziałem, a to jest megaistotna rzecz i brakujaca, bardzo tego brakuje $w$ ofercie leczenia, ale to jest ważne też $z$ punktu widzenia osób uzależnionych, żeby osoby bliskie też miały dostęp do takiego leczenia. (H3003M2)

$W$ tym wszystkim ma olbrzymi problem rodzina, mą̇̇, żona, dzieci pacjenta, którzy są kompletnie zagubieni, nie wiedza co robić. Ważna jest kwestia wsparcia, terapii, tak jak np. w przypadku rodzin osób uzależnionych od alkoholu, bo oni nie wiedza co robić. (PS2804M2)

Takiej pomocy całościowej w tym sensie, że nie chodzi tu wyłacznie o leczenie objawów, tylko o różne konsekwencje życiowe, jakie sq z tym zwiazane. Rodzina zaczyna się sypać i relacje tych ludzi. Pomocy terapeutycznej wymaga wtedy nie sam pacjent, tylko całe środowisko, rodzina, w której się znajduje. (PS2104M1)

\section{Udział ruchów samopomocowych i organizacji społecznych $w$ rozwiązywaniu problemu hazardowego}

Wątek ruchów samopomocowych, zwłaszcza typu Anonimowi Hazardziści, pojawiał się w wypowiedziach wielu respondentów reprezentujących zarówno pacjentów, jak i profesjonalistów. Jeden z przedstawicieli opieki społecznej mówi szerzej o perspektywach włączenia do rozwiązywania problemu hazardowego także organizacji pozarządowych.

Wydaje mi się, że przy takiej strukturze i możliwościach prawnych najlepiej jakby to wzięty organizacje pozarządowe. Jakieś organizacje pozarządowe, które robia wspaniałe rzeczy. Ona [organizacja pozarządowa - aut.] jest elastyczna, może reagować $i$ widzi 
to a reduction in the frequency of relapses and to maintain the positive results of therapy.

A person who completes treatment [at the basic level - auth.] (...) should not finish therapy at this level. I finished therapy and suddenly had a year in which I didn't drink and had two incidents with gambling (...) I felt ever lonelier with my problem as I didn't drink or gamble, but had nobody to talk about it to. And only after a year did a friend, with whom I attended the group, call me up accidently, as he had simply called the wrong number. And he told me that he goes to the kind of group for deepening therapy and that I could perhaps pop in. So I did and now I'm starting from September. (H1605M1)

\section{Scientific research}

During the discussion on treatment proposals were forwarded to undertake research on gambling in Poland that would include Polish specific perspective and would make health and social policy more evidence based. Certain respondents also see the need for widening the area of conducted study to beyond medicine and suggested the necessity of considering the cultural and social component of the phenomenon.

I think the situation has never been studied, especially not in Poland. Cultural differences may be very great between various countries as far as the place of gambling in the whole culture is concerned. And mainly here in our changing culture. (PS2301M1)

\section{- Discussion}

The article has been written on the basis of the results of research on evaluation of the availability of gambling disorder treatment in Warsaw. The recommendations for an improvement in the situation within the scope of providing aid to persons with gambling disorders were declared both by patients and assisted them professionals.

The collected material provided the basis to formulate a series of recommendations going beyond the narrowly understood question of treatment. The recommendations concerned areas associated with the limiting availability of gambling, information and education, increasing access to treatment, improving the quality and adequacy of treatment and scientific research. The matter was discussed in greater detail within these areas. z bliska problemy. (...) Placówka [medyczna - aut.] jako instytucja, to już potem kwestia dogadania się, kto by się tego podjąt. Ale sama terapia czy diagnoza, czy rozeznanie sie, to wydaje mi się, że organizacje pozarzadowe byłyby najlepsze. (OPS1002K1)

\section{Zapewnienie oferty postterapeutycznej}

Potrzebę zapewnienia opieki postterapeutycznej sygnalizowały osoby z zaburzeniami hazardowymi. Objęcie taką formą terapii osób, które kończą leczenie, mogłoby przyczynić się do zmniejszenia częstości występowania nawrotów i do utrzymania pozytywnych wyników leczenia.

Osoba, która skończy leczenie [na poziomie podstawowym - aut.] (...), nie powinna na tym kończyć terapii. Ja skończyłem terapię i nagle miałem taki rok, że faktycznie nie piłem, miałem jakąś wpadkę dwa razy $z$ graniem (...) Czułem się coraz bardziej samotny $w$ swoim problemie, bo nie piłem, nie grałem, ale nie miałem $z$ kim o tym porozmawiać. I dopiero po roku zadzwonit do mnie kolega, z którym kiedyś na grupę chodziłem, bo się pomylit po prostu. I powiedział, że właśnie on chodzi na taka grupe, terapię pogłębiona i żebym może wpadt. No i wpadłem i teraz od września chodze z powrotem. (H1605M1)

\section{Badania naukowe}

Postulaty podjęcia w Polsce badań nad hazardem, które uwzględniałyby polską specyfikę i pozwoliłyby oprzeć politykę zdrowotną i społeczną na wynikach badań naukowych, pojawiały się przy okazji dyskusji o lecznictwie. Niektórzy respondenci widzieli również potrzebę poszerzenia obszaru prowadzonych badań poza sferę medycyny, postulowali konieczność uwzględnienia kulturowego i społecznego komponentu tego zjawiska.

Myślę, że te sytuacje nigdy nie zostały zbadane, szczególnie w Polsce. Różnice kulturowe moga być bardzo duże między różnymi krajami, jeśli idzie o umiejscowienie hazardu w całej kulturze, a u nas $w$ tej zmieniajacej się kulturze. (PS2301M1)

\section{- Omówienie}

Artykuł został napisany na podstawie wyników badań nad oceną dostępności leczenia zaburzeń hazardowych w Warszawie. Rekomendacje dla poprawy sytuacji w zakresie świadczenia pomocy osobom z zaburzeniami hazardowymi zostały zgłoszone zarówno przez pacjentów, jak i udzielających im pomocy profesjonalistów. 
Research in the area of alcohol policy showed that limitation of physical and economic availability influences consumption limitation [26]. Among the instruments that limit supply, are prices, bans on underage sales, places of sale and opening times limitation and state monopoly [27]. Introduction of this kind of instrument in the area of gambling policy may be an effective action allowing for the limitation of the spread of gambling and the problems associated with it. Among the recommendations addressed to limiting the availability of gambling were suggestions to reduce the possibility of participating in gambling and especially access to slot machines and Internet gambling, introduction of opening time limitations and a ban on underage gambling.

According to the study results, information and education have a relatively small influence on behaviour associated with alcohol consumption [28, 29]. They can however increase social awareness of the problem's risks and raise its importance among other problems, locate it higher on social and health policy priority lists and finally rise the level of acceptance for evidence based policy. The recommendations as regards the information and education concerning gambling disorders included three areas: mass media campaigns, school education and warning information at gambling sites.

Respondents' recommendations associated with increasing the availability of treatment as well as its quality and adequacy are significant from the point of view of barriers people encounter identified in the study $[24,30]$. Decisions to publicise treatment by persons with gambling disorders are determined by exactly such barriers.

Among the recommendations that could contribute to an improvement in the situation as regards aid provision to persons with gambling disorders are the necessity of scientific research, the results of which would be the basis for introducing changes in health and social policy. Evidence based changes allow the shaping of appropriate policy and the undertaking of effective initiatives [31].

The presented study has its limitations. First, the participants were associated with medical care; that is, either those in treatment or who had received treatment due to gambling disorders. There was a lack of respondents who had never undertaken treatment and whose opinions could have
Zebrany materiał dostarczył podstaw do sformułowania serii rekomendacji wychodzących poza wąsko rozumiane kwestie lecznictwa. Rekomendacje dotyczyły obszarów związanych z ograniczaniem dostępności hazardu, informacją i edukacją, dostępnością leczenia, poprawą jakości i adekwatności leczenia, badaniami naukowymi. W ramach tych obszarów wyróżniono kwestie bardziej szczegółowe.

Badania z obszaru polityki alkoholowej pokazują, że ograniczanie dostępności fizycznej i ekonomicznej wpływa na ograniczenie spożycia [26]. Wśród instrumentów, które ograniczają podaż, można wyróżnić ceny, zakaz sprzedaży nieletnim, ograniczenia co do godzin i miejsc sprzedaży, monopol państwa [27]. Wprowadzenie tego rodzaju instrumentów w dziedzinie polityki hazardowej może być skutecznym działaniem pozwalającym na ograniczenie rozpowszechnienia grania i problemów z tym związanych. Wśród rekomendacji odnoszących się do ograniczenia dostępności hazardu znalazły się te postulujące zmniejszenie możliwości uprawiania hazardu, a zwłaszcza dostępu do automatów do gry i hazardu w Internecie, wprowadzenie ograniczeń co do godzin otwarcia oraz zakazu uprawiania hazardu przez niepełnoletnich.

Według wyników badań informacja i edukacja mają stosunkowo niewielki wpływ na zachowania związane ze spożyciem alkoholu [28, 29]. Mogą jednak zwiększyć w społeczeństwie świadomość zagrożenia problemem, podnieść jego rangę wśród innych problemów, ulokować wyżej na liście priorytetów polityki społecznej i zdrowotnej i wreszcie - podnieść poziom akceptacji dla polityki mającej podstawy w wynikach badań naukowych. Rekomendacje co do informacji i edukacji dotyczących zaburzeń hazardowych zawierały się w trzech obszarach: prowadzenia kampanii w środkach masowego przekazu, edukacji szkolnej oraz informacji ostrzegawczych w miejscach uprawiania hazardu.

Rekomendacje respondentów związane ze zwiększeniem dostępności leczenia oraz jego jakości i adekwatności są istotne z punktu widzenia zidentyfikowanych w badaniach barier, jakie napotykają osoby podejmujące terapię $[24,30]$. Decyzja o rozpoczęciu leczenia przez osoby z zaburzeniami hazardowymi jest determinowana przez te właśnie bariery.

Wśród rekomendacji, które mogłyby się przyczynić do poprawy sytuacji w zakresie świadczenia pomocy osobom z zaburzeniami hazardowymi, pojawiła się konieczność prowadzenia badań naukowych, których wyniki byłyby podstawą do 
been important from the perspective of the suggested changes in the treatment system. Second, the strategy of respondent selection could have influenced their answers. Third, there is only a small number of centres carrying out treatment for gambling disorder persons in Warsaw, so patients experience is limited, which could have had an effect on the variation of opinion concerning changes in treatment.

\section{- Conclusions}

The formulated recommendations go beyond the narrowly understood matters of treatment. They concern areas like limiting the availability of gambling, information and education, increasing access to treatment, improving the quality and adequacy of treatment and scientific research. Within these areas the following more detailed matters were identified.

1. Availability limitation:

- reducing the possibility of gambling and especially access to slot machines and Internet gambling,

- introducing limitations as to opening hours for gambling sites,

- introduction and execution of a ban on underage gambling.

2. Information and education:

- mass media campaigns,

- school education,

- warning information at gambling sites.

3. Access to treatment:

- increasing the number of programmes for people with gambling disorders,

- reducing waiting times for treatment,

- improvement of information on possibility of treatment,

- referral for treatment by general practitioners and specialists,

- ensuring the possibility of treatment harmonised with work duties.

4. Improvement in treatment quality and adequacy:

- training in gambling disorders,

- cooperation between different professions and institutions so that the aid provision were interdisciplinary,

- ensuring the minimum competent offer at primary health care centres, wprowadzanie zmian w polityce zdrowotnej i społecznej. Zmiany mające podbudowę w dowodach naukowych pozwalają kształtować odpowiednią politykę i podejmować skuteczne inicjatywy [31].

Przedstawione badanie ma swoje ograniczenia. Po pierwsze, w badaniu wzięły udział osoby związane z lecznictwem, czyli te które leczą się bądź leczyły się z powodu zaburzeń hazardowych. Wśród respondentów zabrakło osób, które nigdy nie podejmowały leczenia, a których opinie mogłyby być istotne $\mathrm{z}$ perspektywy postulowanych zmian w systemie leczenia. Po drugie, strategia doboru respondentów mogła mieć wpływ na udzielane przez nich wypowiedzi. Po trzecie, w Warszawie jest niewielka liczba placówek prowadzących leczenie dla osób z zaburzeniami hazardowymi, przez co doświadczenia pacjentów są ograniczone, co mogło mieć wpływ na zróżnicowanie opinii dotyczących zmian w lecznictwie.

\section{- WNIOSKI}

Sformułowane rekomendacje wychodzą poza wąsko rozumiane kwestie lecznictwa. Dotyczą one obszarów: ograniczanie dostępności hazardu, informacja i edukacja, dostępność leczenia, poprawa jakości i adekwatności leczenia, badania naukowe. W ramach tych obszarów wyróżniono kwestie bardziej szczegółowe.

1. Ograniczanie dostępności:

- zmniejszenie możliwości uprawiania hazardu, a zwłaszcza dostępu do automatów do gry i hazardu w Internecie,

- wprowadzenie ograniczeń co do godzin otwarcia punktów uprawiania hazardu,

- wprowadzenie i egzekwowanie zakazu uprawiania hazardu przez niepełnoletnich.

2. Informacja i edukacja:

- kampanie prowadzone w środkach masowego przekazu,

- edukacja szkolna,

- informacje ostrzegawcze w miejscach uprawiania hazardu.

3. Dostępność leczenia:

- zwiększenie liczby programów dla osób z zaburzeniami hazardowymi,

- skrócenie czasu oczekiwania na leczenie,

- poprawa informacji na temat możliwości leczenia,

- kierowanie do leczenia przez lekarzy podstawowej opieki zdrowotnej i lekarzy specjalistów, 
- development of specialised programmes for gambling disorder persons and for comorbid psychoactive substance dependencies,

- widening the offer for active gamblers (controlled gambling programmes and changes in gambling pattern),

- financial management skills training,

- ensuring family therapy service for families of gambling disorder persons,

- involving self-help movements and social organisations in solving the gambling problem,

- ensuring post-therapy care to people with gambling disorders.

5. Development of scientific research concerning gambling related problems.
- zapewnienie możliwości leczenia niekolidującymi z obowiązkami zawodowymi.

4. Poprawa jakości i adekwatności leczenia:

- szkolenia w zakresie zaburzeń hazardowych,

- współpraca między różnymi profesjonalistami, instytucjami, tak aby oferta pomocy była wielodyscyplinarna,

- zapewnienie minimalnej kompetentnej oferty w placówkach podstawowej opieki zdrowotnej,

- opracowanie wyspecjalizowanych programów dla osób z zaburzeniami hazardowymi, w tym programów dla współwystępujących $\mathrm{z}$ hazardem uzależnień od substancji psychoaktywnych,

- poszerzenie oferty dla czynnych graczy (programy grania kontrolowanego, zmiana wzoru grania),

- uczenie umiejętności zarządzania finansami,

- zapewnienie terapii rodzinom osób z zaburzeniami hazardowymi,

- zaangażowanie ruchów samopomocowych/organizacji społecznych w rozwiązywanie problemu hazardowego,

- zapewnienie opieki postterapeutycznej osobom z zaburzeniami hazardowymi.

5. Rozwijanie badań naukowych dotyczących problemów związanych $\mathrm{z}$ hazardem.

\section{Conflict of interest/Konflikt interesów}

None declared./Nie występuje.

\section{Financial support/Finansowanie}

Research was cofinanced from the resources of Prevention Gambling Problems Fund, Ministry of Health./Badanie zostało współfinansowane ze środków Funduszu Rozwiązywania Problemów Hazardowych, będących w dyspozycji Ministra Zdrowia.

\section{Ethics/Etyka}

The work described in this article has been carried out in accordance with the Code of Ethics of the World Medical Association (Declaration of Helsinki) on medical research involving human subjects, EU Directive (210/63/EU) on protection of animals used for scientific purposes, Uniform Requirements for manuscripts submitted to biomedical journals and the ethical principles defined in the Farmington Consensus of 1997./Treści przedstawione w pracy są zgodne z zasadami Deklaracji Helsińskiej odnoszącymi się do badań z udziałem ludzi, dyrektywami EU dotyczącymi ochrony zwierząt używanych do celów naukowych, ujednoliconymi wymaganiami dla czasopism biomedycznych oraz z zasadami etycznymi określonymi w Porozumieniu z Farmington w 1997 roku.

Permission for the study was gained from the Bioethics Committee at the Institute of Psychiatry and Neurology in Warsaw/Na realizację badania uzyskano zgodę Komisji Bioetycznej działającej przy Instytucie Psychiatrii i Neurologii w Warszawie, Polska (ref. 24/2015). 


\section{References/Piśmiennictwo}

1. CBOS. Oszacowanie rozpowszechnienia oraz identyfikacja czynników ryzyka i czynników chroniacych $w$ odniesieniu do hazardu, w tym hazardu problemowego (patologicznego) oraz innych uzależnień behawioralnych. Warszawa: Centrum Badania Opinii Społecznej; 2012.

2. St-Pierre R, Walker D, Derevensky J, Gupta R. How Availability and Accessibility of Gambling Venues Influence Problem Gambling: A Review of the Literature. Gaming Law Rev \& Economics 2014; 18(2): 150-72. DOI: 10.1089/glre.2014.1823.

3. Raylu N, Oei TP. Pathological gambling. A comprehensive review. Clin Psychol Rev 2002; 22(7): 1009-61.

4. Petry NM, Blanco C, Auriacombe M, Borges G, Bucholz K, Crowley T, et al. An Overview of rationale for changes proposed for pathological gambling in DSM-5. J Gambl Stud 2014; 30(2): 493-502.

5. Shaffer HJ, Hall MN. Updating and refining prevalence estimates of disordered gambling behavior in the United States and Canada. Can J Public Health 2001; 92(3): 168-72.

6. Tavares H. Gambling in Brazil: a call for an open debate. Addict 2014; 109: 1972-76.

7. Wardle H, Moody A, Spence S, Orford J, Volberg R, Jotangia D, et al. British gambling prevalence survey 2007. Executive summary, 2011. Available from: http:/www.natcen. ac.uk/our-research/research/british-gambling-prevalence-survey/ [Accessed: 12.01.2016].

8. Erbas B, Buchner U. Pathological Gambling Prevalence, Comorbidity, Diagnosis, and Intervention in Germany. Dtsch Ärztebl Int 2012; 109(10): 173-9.

9. Sharman S, Dreyer J, Aitken M, Clark L, Bowden-Jones H. Rates of Problematic Gambling in a British Homeless Sample: A Preliminary Study. J Gambl Stud 2015; 31(2): 525-32.

10. Suurvali H, Hodgins D, Toneatto T, Cunningham J. Motivators for seeking gambling-related treatment among Ontario problem gamblers. J Gambl Stud 2012; 28: 273-96.

11. Evans L, Delfabbro PH. Motivators for change and barriers to help-seeking. J Gambl Stud 2015; 21(2): 133-55.

12. CBOS. Oszacowanie rozpowszechnienia wybranych uzależnień behawioralnych oraz analiza korelacji pomiędzy występowaniem uzależnień behawioralnych a używaniem substancji psychoaktywnych. Warszawa: Centrum Badania Opinii Społecznej; 2015.

13. Cunningham J. Little use of treatment among problem gamblers. Psychiatr Serv 2005; 56: 1024-5.

14. Petry NM. Pathological gambling: etiology, comorbidity and treatment, $1^{\text {st }}$ ed. Washington, DC: American Psychological Association; 2005.

15. Slutske WS. Natural recovery and treatment-seeking in pathological gambling: Results of two US national surveys. Am J Psychiatry 2006; 163(2): 297-302.

16. Volberg RA, Nysse-Carris KL, Gerstein DR. California problem gambling prevalence survey. Final Report, 2006. Available from: http://www.standupca.org/reports/CA_Problem_Gambling_Prevalence_Survey-Final_Report.pdf [Accessed: 12.01.2016].

17. Suurvali H, Hodgins D, Toneatto T, Cunningham J. Treatment seeking among Ontario problem gamblers: results of a population survey. Psychiatr Serv 2008; 59(11): 1343-6.

18. Productivity Commission. Australia's gambling industries. Canberra: Productivity Commission; 1999.

19. Ministry of Health. Preventing and minimizing gambling harm. Three year service plan 2007-2010. Wellington, New Zealand: Ministry of Health; 2007.

20. Hodgins DC, Stea JN, Grant JE. Gambling disorders. Lancet 2011; 378(9806): 1874-84.

21. Hing N, Russell A, Gainsbury S, Nuske E. The Public Stigma of Problem Gambling: Its Nature and Relative Intensity Compared to Other Health Conditions. J Gambl Stud 2015; published online 20 October, 1-18.

22. Olason D, Hayer T, Brosowski T, Meyer G. Gambling in the Mist of Economic Crisis: Results from Three National Prevalence Studies from Iceland. J Gambl Stud 2015; 31 : 759-74.

23. Suurvali H, Cordingley J, Hodgins DC, Cunningham J. Barriers to seeking help for gambling problems: a review of the empirical literature. J Gambl Stud 2009; 25(3): 407-24. 
24. Dąbrowska K, Moskalewicz J, Wieczorek Ł. Barriers in Access to the Treatment for People with Gambling Disorders. Are They Different from Those Experienced by People with Alcohol and/or Drug Dependence? J Gambl Stud 2016; 33: 487-503. DOI: 10.1007/ s10899-016-9655-1.

25. Wasilewska E. Statystyka opisowa nie tylko dla socjologów. Warszawa: Wydawnictwo SGGW; 2008.

26. Mäkela K, Room R, Single E, Sulkunen P, Walsh B, Bunce R, et al. Alcohol, Society, and the State 1: A Comparative Study of Alcohol Control. Toronto: Addiction Research Foundation; 1981.

27. Babor T, Caetano R, Casswel S, Edwards G, Giesbrecht N, Graham K, et al. Alcohol no ordinary commodity. Research and Policy. Oxford University Press; 2003.

28. Österberg E, Karlsson T. Alcohol Policies in EU Member States and Norway. A Collection of Country Reports. Helsinki, Finland: STAKES; 2002.

29. Anderson P, Baumberg B. Alcohol in Europe. A Public Health Perspective. A report for the European Commission. United Kingdom: Institute of Alcohol Studies; 2006.

30. Gainsbury S, Hing N, Suhonen N. Professional help-seeking for gambling problems: Awareness, barriers and motivators for treatment. J Gambl Stud 2014; 30: 503-19. DOI: 10.1007/s10899-013-9373-x.

31. Szarfenberg R. Dowody naukowe jako podstawa polityki społecznej, zarządzania społecznego i pracy socjalnej. Problemy Polityki Spotecznej. Studia i Dyskusje 2011; 15: 13-28. 